\title{
Does the MMPI-2 College Maladjustment Scales Affect the Mini-Quiz Score of Students in the Medical Study Program of Universitas Muhammadiyah Yogyakarta?
}

\author{
Sri Sundari ${ }^{1}$, Fitri Nurjanah ${ }^{2}$
}

${ }^{1 *}$ Correspondence Author: sundari_purbo@yahoo.com.sg

1,2Medical Study Program of FKIK Universitas Muhammadiyah Yogyakarta, Bantul, Indonesia

\begin{tabular}{l}
\hline I N D E X I N G \\
\hline Keywords: \\
MMPI-2; \\
Student; \\
Universitas \\
Muhammadiyah \\
Yogyakarta.
\end{tabular}

Kata Kunci:

MMPI-2;

Mahasiswa;

Universitas

Muhammadiyah

Yogyakarta.

\begin{abstract}
A B S T R AC T
A student, especially a new student, will adjust their environment in their first year of college, from high school to higher education. During the adjustment process, freshman experience various kinds of changes in the Higher Education environment. These changes both academically and non-academically. This research is a quantitative analytic observational research with cross sectional approach. The population used in this study were new students of the 2018 class of the Medical Study Program at Universitas Muhammadiyah Yogyakarta. There were 150 new student batch 2018 as population of the study. Based on the results and discussion, it can be concluded that there is no significant relationship between the MMPI-2 College Maladjustment Scales (Mt) and the mini-quiz score. It is suggested to have further research with more mini-quiz scores in blocks, research on factors that affect learning outcomes, and involve other aspects of learning outcomes, not only miniquiz scores but also final block evaluation scores, tutorial scores and practicum scores.
\end{abstract}

\begin{abstract}
Seorang mahasiswa, khususnya mahasiswa baru, akan menyesuaikan diri dengan lingkungannya di tahun pertama kuliah, mulai dari sekolah menengah hingga pendidikan tinggi. Selama proses penyesuaian, mahasiswa baru mengalami berbagai macam perubahan di lingkungan Perguruan Tinggi. Perubahan ini baik secara akademis maupun non-akademik. Penelitian ini merupakan penelitian observasional analitik kuantitatif dengan pendekatan cross sectional. Populasi yang digunakan dalam penelitian ini adalah mahasiswa baru angkatan 2018 Program Studi Kedokteran Universitas Muhammadiyah Yogyakarta. Jumlah mahasiswa baru angkatan 2018 sebanyak 150 orang sebagai populasi penelitian. Berdasarkan hasil dan pembahasan dapat disimpulkan bahwa tidak ada hubungan yang signifikan antara Skala Maladjustment (Mt) Perguruan Tinggi MMPI-2 dengan skor mini-quiz. Disarankan untuk penelitian lebih lanjut dengan lebih banyak skor mini kuis dalam blok, penelitian tentang faktor-faktor yang mempengaruhi hasil belajar, dan melibatkan aspek lain dari hasil belajar, tidak hanya skor kuis mini tetapi juga skor evaluasi blok akhir, skor tutorial dan skor praktikum.
\end{abstract}

2021 JMMR All rights reserved

\section{INTRODUCTION}

A student, especially a new student, will make adjustments to their environment in their first year of college, from high school to higher education. During the adjustment process, freshman experience various kinds of changes in the Higher Education environment. These changes both academically and non-academically. Non-academic problems will arise when there is a social pressure experienced by students such as pressure, conflict and a lack of learning facilities. In addition, academic problems will also arise when students are unable to adapt to the study program also unable to attend lecture activities properly (Hidayat, 2011). In fact, many medical students have adjusting difficulty during their education (Dunn et al., 2008).

Adjustment means adapt to the new environment. Besides, it can also mean changing the environment according to personal desires (Gerungan, 1991). If students are unable to adjust themselves well to their lectures, it will affect their learning outcomes or learning achievement 
(Suryabrata, 1988). Medical students are identic with high levels of stress and depression (Compton et al., 2008). Research conducted on medical students by Marita in 2011 at the Universitas Muhammadiyah Malang showed that first-year medical students had a higher stress level than those in the third year (Aryani, 2011). Research at the Faculty of Medicine, Sam Ratulangi Manado by Pertiwi, et al. in 2018 found that the highest scale of MMPI-2 in first semester was College Study at 25.74\% which indicates that students have less psychological adaptability, are pessimistic and feel useless (Putri et al., 2018). The state of stress that occurs in medical students is academic stress, stress that occurs in the scope of learning (Nist-Olejnik et al., 2016).

There are internal and external factors that can influence the learning process. Factors that come from within include physiological and psychological conditions, while factors that come from outside a person are the environment, both the family environment and the community environment (Suryabrata, 1989). Students are expected to be able to participate in lecture activities well but some of them can't do it. For students who experience failure, of course, it is caused by several things. It can be caused by academic problem, mental health, and also personality. Therefore, the identification of a personality is important. It is used to determine the risk of difficulties in studying in the Medical Study Program (Sinamo et al., 2009).

Problems about mental health often occur because they face both psychosocial and psychological problems and improve their learning outcomes (Setiawan, 2015). Evaluation of student learning outcomes is quite diverse, one of them is mini-quiz score. Min-quiz scores are a level the success or failure of the study obtained by students after taking the min-quiz test in each tutorial activity scenario. This score is used to assess how far students understand the material that has been taken.

To predict mental health such as difficulties in adjustment and emotional disturbances that exist or will occur during education. One of the tests that can be used is the Minnesota Multiphasic Personality Inventory (MMPI) test for new students (Knehr \& Kohl, 2010). Minnesota Multiphasic Personality Inventory-2 (MMPI-2) is a test to determine a person's mental health status in the form of personality function, emotional state, psychopathological severity, and can formulate an intervention or treatment (Ganellen, 1996). In the MMPI-2 Supplementary Scales, college maladjustment scales (Mt), to assess a student's inability to adjust. There is a category on the Mt scale with a cut off score of $\mathrm{T} \geq 65$ (High Score), T 41-64 (Moderate Score) and T $\leq 40$ (Low Score). The value of Mt in the high category indicates that the student is unable to adjust himself well. This research was conducted to determine the relationship between the MMPI-2 college maladjustment scales and the mini-quiz score of the Medical Study Program students.

\section{RESEARCH METHODS}

This research is a quantitative analytic observational research with cross sectional approach. The population used in this study were new students of the 2018 class of the Medical Study Program at Universitas Muhammadiyah Yogyakarta. There were 150 new student batch 2018 as population of the study. The sample gotten for this study was 137 students. As the inclusion criteria were students who have passed the MMPI-2 test at the time of selection as a requirement of Medical Study Program, take the $100 \%$ mini-quiz test in blocks 1, 2, 3 and 4 . As the exclusion criteria were students other than batch 2018 FKIK UMY Medical study program. The independent variable (independent) in this study was the MMPI college maladjustment scale $(\mathrm{Mt})$, while the dependent variable was mini-quiz score. In this study, the data used were in the form of data on the results of the College Maladjustment Scale MMPI 2 tests for 2018 students. Data analysis used spearman non-parametric correlation.

\section{RESULT AND DISCUSSION}

Respondents' characteristic gotten from 137 students as sample at Medical Study Program FKIK UMY can be seen in table 1 , table 2, and table 3 . 
Table 1. Respondents' characteristic based on gender

\begin{tabular}{cccc}
\hline Characteristic & Frequency & & $(\%)$ \\
& & 41 & 29.9 \\
\hline Male & 96 & 70.1 \\
\hline Female & & 96 \\
\hline
\end{tabular}

Table 1 show that the most respondents in this study were female, 96 students. And then, the Table 2. shows that there are 34 students who have a high Mt Scale, 9 were male and 25 were female.

Table 2. Respondents' characteristic based on gender and Mt Scale

\begin{tabular}{llccc}
\hline \multirow{2}{*}{ Characteristic } & & \multicolumn{2}{c}{ Gender } & Total \\
\cline { 3 - 4 } & & Male & Female & \\
\hline \multirow{3}{*}{ College } & Low score & 10 & 25 & 35 \\
MaladjustmentScales & $7.3 \%$ & $18.2 \%$ & $25.5 \%$ \\
\cline { 2 - 5 }$(\boldsymbol{M} t)$ & & 22 & 46 & 68 \\
& Moderate & $16.1 \%$ & $33.6 \%$ & $49.6 \%$ \\
\hline Total & score & 9 & 25 & 34 \\
\cline { 2 - 5 } & High score & $6.6 \%$ & $18.2 \%$ & $24.8 \%$ \\
\hline & & 41 & 96 & 137 \\
& & $29.9 \%$ & $70.1 \%$ & $100.0 \%$ \\
\hline
\end{tabular}

Table 3. Students' Mini-quiz Score

\begin{tabular}{cccccc}
\hline Characteristic & Mean \pm SD & Median & Mode & Minimum & Maximum \\
\hline Mini-quiz score & $67.99 \pm 7.80$ & 69.00 & 70 & 43 & 83 \\
\hline
\end{tabular}

Table 4. Spearman Correlation Test

\begin{tabular}{cccccc} 
& \multicolumn{3}{c}{ College Maladjustment Scales } & & $*$ \\
\cline { 1 - 4 } Mini-quiz Score & \multicolumn{3}{c}{ Category } & & \\
\cline { 2 - 4 } & Low score $(\leq 40)$ & $\begin{array}{c}\text { Moderate Score } \\
(41-64)\end{array}$ & High Score $(\geq 65)$ & & \\
\hline \multirow{3}{*}{$67.99 \pm 7.80$} & $(25.5 \%)$ & $(49.6 \%)$ & $34(24.8 \%)$ & 0.070 & 0.155 \\
\hline
\end{tabular}

*Spearman correlation test was $0.070>0.05$. It means that there is no relation between two variables.

${ }^{* *} \mathrm{r}$ score was 0.155 can be categorized as poor correlation with positive direction.

Based on the table results, it was found that there was no significant relationship between the MMPI-2 College Maladjustment Scales (Mt) and the mini-quiz score. In this study the correlation is very weak with a positive correlation direction indicating that the higher the MMPI-2 College Maladjustment Scales $(\mathrm{Mt})$ score of students, the higher the mini-quiz score. It contradicts to the interpretation guidelines published by the University of Minnesota Press. The higher the MMPI-2 College Maladjustment Scales (Mt) score, the lower the mini-quiz score will be, because it is unable to adjust properly. Adjustment is a defense that is acquired from birth or gained from learning to deal with stress and is also a task-oriented way of adjustment (Sunaryo, 2004). Students who have difficulty adapting can experience disruption in their interactions with the environment both with lecturers and friends. The ability to adapt will vary between individuals. This is because the adjustment process is influenced by several factors, namely social, personal, social education and financial factors (Graham, 2012).

This study is in line with research by Christyanti et al., (2010) which concluded that there is a significant relationship with the direction of negative correlation and about $83.8 \%$ of other factors influence the tendency of stress in medical students, including environmental factors, personality 
factors and behavior patterns. type A, cognitive factors and socio-cultural factors. However, this study contradicts with previous research conducted by Fitria \& Susandari (2019) that there is a significant relationship between College Adjustment and learning achievement which shows that the higher the College Adjustment of the 2017 UNISBA psychology faculty students, the higher the learning achievement. Besides that, it is also different from the research conducted by Suryadi et al., (2020) which indicates a significant positive relationship between adjustment and student achievement.

According to Schneider's, there are 5 factors that influence the adjustment process, namely: physical condition, personality, learning process, environment, religion and culture (Ali \& Asrori, 2011). In addition to factors that affect self-adjustment, there are also factors that can affect learning outcomes. Factors that influence learning outcomes are categorized into three, namely: internal factors, external factors, and instrument factors. Internal factors, namely factors that can influence learning that comes from students during learning, such as interest and motivation to learn. High student interest in learning causes student learning to be easier and faster. Motivation to learn is influenced by several factors, namely: ideals, learning abilities, student conditions, environmental conditions, dynamic elements in learning, and teacher teaching efforts. External factors, namely factors originating from outside students that affect the learning process and outcomes. Among them is the social environment. The presence of other people who can interfere with learning activities. One of these social environments is the environment of students at school consisting of peers, other classmates, teachers, school principals and other employees who can also influence individual learning processes and outcomes. Instrument factors are factors related to learning tools such as curriculum, program structure, learning facilities and infrastructure (learning media), and teachers as instructional designers. In using these learning tools, the teacher must design them according to the expected results (Suryabrata, 1989).

Apart from the above factors, there are other factors that can affect learning outcomes, namely internal and external factors. Internal factors that come from students themselves such as psychological conditions, interests, intelligence and readiness. While external factors are friends, family, curriculum, and institutions (Istadi \& Prabandari, 2012). Mini-quiz scores as an indicator of learning outcomes also affect research results. The quality, level of complexity and breadth of the material in the scenario will also affect the mini-quiz questions. Another factor that affects learning outcomes is the tutor's performance which has the same influence as the learning method, learning motivation and the interaction of members in the study group (Slameto, 2003).

Even though the variables used in the previous study were almost the same, namely an indicator of learning outcomes, there are many factors that can affect a person's adjustment and learning outcomes. So that in this study, researchers got different results from previous research. Apart from that, the factors above are also important references regarding the relationship between the MMPI-2 College Maladjustment Scales (Mt) and learning outcomes in the form of mini-quiz scores.

\section{CONCLUSION}

Based on the results and discussion, it can be concluded that there is no significant relationship between the MMPI-2 College Maladjustment Scales (Mt) and the mini-quiz score. It is suggested to have further research with more mini-quiz scores in blocks, research on factors that affect learning outcomes, and involve other aspects of learning outcomes, not only miniquiz scores but also final block evaluation scores, tutorial scores and practicum scores.

\section{ACKNOWLEDGMENT}

We would like to express our gratitude to the research, publication and community service institutions Universitas Muhammadiyah Yogayakarta that has provided funding in this research. 


\section{REFERENCE}

Ali, M., \& Asrori, M. (2011). Psikologi Remaja: Perkembangan peserta didik / Mohammad Ali dan Mohammad Asrori. Bumi Aksara.

Aryani, M. D. (2011). Perbedaan Tingkat Stres Mahasiswa Kedokteran Pada Tahun Pertama dan Tahun Ketiga di Universitas Muhammadiyah Malang. Universitas Muhammadiyah Malang.

Christyanti, D., Mustami'ah, D., \& Sulistiani, W. (2010). Hubungan antara Penyesuaian Diri terhadap tuntutan akademik dengan kecenderungan stres pada mahasiswa Fakultas Kedokteran Universitas Hang Tuah Surabaya. Directory of Open Access Publication Universitas Hang Tuah Surabaya. https://dspace.hangtuah.ac.id/xmlui/handle/dx/585

Compton, M. T., Carrera, J., \& Frank, E. (2008). Stress and depressive symptoms/dysphoria among US medical students: results from a large, nationally representative survey. Journal of Nervous and Mental Disease, 196(12), 891-897. https://pubmed.ncbi.nlm.nih.gov/19077856/

Dunn, L. B., Iglewicz, A., \& Moutier, C. (2008). A conceptual model of medical student wellbeing: promoting resilience and preventing burnout. Acad Psychiatry, 32(1), 44-53.

Fitria, Z., \& Susandari. (2019). Hubungan Antara College Adjustment dengan Prestasi Belajar Mahasiswa Fakultas Psikologi Unisba Angkatan 2017 yang Berprestasi Rendah. Prosiding Psikologi.

Ganellen, R. (1996). Integrating the Rorschach and the MMPI-2 in Personality Assessment. Routledge.

Gerungan, W. . (1991). Psikologi Sosial. PT Eresco.

Graham, J. . (2012). MMPI-2: Assessing personality and psychopathology (5th edition). Oxford University Press.

Hidayat, D. R. (2011). Permasalahan Mahasiswa. PT BPK Gunung Mulia.

Istadi, Y., \& Prabandari, Y. S. (2012). Faktor-Faktor yang Dianggap Sebagai Prediktor Terhadap Keefektifan Kelompok Tutorial Problem Based Learning (PBL). Jurnal Pendidikan Kedokteran Indonesia, 1(2).

Knehr, C., \& Kohl, R. (2010). MMPI screening of entering medical students. The Journal of Psychology: Interdisciplinary and Applied, 297-304.

Nist-Olejnik, S., Holschuh, J., \& Holschuh, J. P. (2016). College rules! How to study, survive, and succeed. Ten Speed Press.

Putri, P. P., Sukohar, A., Wahyudo, R., \& Lisiswanti, R. (2018). Hubungan Hasil Tes Minnesota Multiphasic Personality Inventory 2 (Mmpi-2) dengan Indeks Prestasi 
Kumulatif Mahasiswa Angkatan 2016 Fakultas Kedokteran Universitas Lampung. Medical Journal of Lampung University, 7(2).

Setiawan, M. (2015). Hubungan Tingkat Depresi dengan Indeks Prestasi Kumulatif pada Mahasiswa Fakultas Kedokteran Universitas Kristen Maranatha Semester Enam Angkatan 2012. Universitas Kristen Maranatha.

Sinamo, S. J., Suak, D., \& Munayang, H. (2009). Profil Kepribadian Mahasiswa Fakultas Kedokteran Universitas Sam Ratulangi yang Belum Menyelesaikan Studi Tahap Akademik Selama Lebih dari Enam Tahun Berdasarkan MMPI-2. Jurnal Biomedik, 1(2), 87-95. https://ejournal.unsrat.ac.id/index.php/biomedik/article/view/816

Slameto. (2003). Belajar dan Faktor-faktor yang mempengaruhinya. Rineka Cipta.

Sunaryo. (2004). Psikologi untuk Keperawatan. EGC.

Suryabrata, S. (1988). Psikologi Kepribadian. Rajawali.

Suryabrata, S. (1989). Psikologi Kepribadian. PT. Raja Grafindo Persada.

Suryadi, Triyono, Nur, A., \& Dianto, M. (2020). Hubungan Penyesuaian Diri dan Motivasi Belajar Dengan Prestasi Belajar Siswa. Jurnal NeoKonseling, 2(1). http://neo.ppj.unp.ac.id/index.php/neo/article/view/252 